\title{
Embedding Law in Participatory Processes Enables an Ecosystem Approach to Marine Decision Making: Analysis of a North Sea Example
}

\author{
Anne-Michelle Slater and Alison MacDonald
}

In Scotland, marine spatial planning (MSP) is still both a new idea and a new legal process. The legislation and policy enacted and developed to implement MSP has been subject to a long gestation period followed by extensive consultation. ${ }^{1}$ The recent development of laws in the UK and Scotland reflects a particular UK and Scottish perspective on MSP but also the emerging EU law and policy on maritime spatial planning. ${ }^{2}$ Integral to the new MSP regime is the requirement to adopt and enshrine in law an ecosystem approach to marine decision-making. ${ }^{3}$ Implementing the ecosystem approach is a novel and challenging idea, in terms of both process and outcomes. There is also no generally accepted method for its implementation in marine planning.

1 SP Bill 25 Marine (Scotland) Bill [as introduced] Policy Memorandum Session 3 (2009) <www.parliament.scot/S3_Bills/Marine\%2o(Scotland)\%2oBill/b25s3-introd-pm.pdf > accessed 30 November 2017; Marine Scotland, Scotland's National Marine Plan Sustainability Appraisal Post Adoption Statement (March 2016) <www.gov.scot/Resource/o049/o0498327 .pdf> accessed 14 November 2017.

2 Directive 2008/56/EC of the European Parliament and of the Council of 17 June 2008 establishing a framework for community action in the field of marine environmental policy (Marine Strategy Framework Directive) [2008] OJ L164/19. It is noted that Directive 2008/56/ EU has subsequently been amended by Commission Directive (EU) 2017/845 [2017] OJ L125/27. Directive 2014/89/EU of the European Parliament and of the Council of 23 July 2014 establishing a framework for marine spatial planning [2014] OJ L257/135.

3 Article 5 (1) of MSP Directive requires an ecosystem approach 'When establishing and implementing maritime spatial planning, Member States shall consider economic, social and environmental aspects to support sustainable development and growth in the maritime sector, applying an ecosystem-based approach, and to promote the coexistence of relevant activities and uses.' Article 3 (5) of the MSFD which provides the definition of GES states 'Adaptive management on the basis of the ecosystem approach shall be applied with the aim of attaining good environmental status.'

(C) ANNE-MICHELlE SLATER AND ALISON MACDONALD, 2019 | DOI:10.1163/9789004389984_010 This is an open access chapter distributed under the terms of the prevailing CC-BY-NC License at the time of publication. 
The Cooperative Participatory Evaluation of Renewable Technologies on Ecosystem Services (CORPORATES) Project, which provides the foundation for this chapter, was based on the documented demand for a decision making framework that could balance socio-economic and ecological issues. ${ }^{4}$ The interdisciplinary research group assembled for CORPORATES proposed to build on earlier research that concluded that such a framework would enable implementation of the ecosystem approach and in particular could facilitate policy development. ${ }^{5}$ It was clear that across disciplines, and emerging relatively rapidly, there was a growing body of academic thought, working practices, and policy contexts around the implementation of the ecosystem approach in general terms. The CORPORATES project therefore, proposed that this expertise could be combined with that of those who had direct experience and knowledge of the marine environment in Scotland, to work together to develop a clear process that implemented the ecosystem approach in marine planning decisions.

The project sought to address three questions. First, could a process be developed that linked ecosystem services with MSP? Second, could the role of the law be maximised to enable and enhance the development and implementation of the process? Third, could a process be developed which increased acceptance and understanding by all stakeholders in decisions to locate large scale Marine Renewable Energy installations (MRE)? The project worked over an 18-month period to develop such a process, which, after testing, was considered to have answered these questions in the affirmative. The overall conclusions were threefold: first, that the process built a greater and shared understanding of the ecological and policy linkages and interactions; second, that the deliberative techniques developed in the context of environmental services and ecological trade-offs can reduce conflicts and facilitate planning; third, that the decision support system that was developed should be employed early in the planning process for maximum impact. ${ }^{6} \mathrm{~A}$ unique feature of the CORPORATES project was the use of real-life cases, in the form of four large offshore wind farms proposed in the North Sea, ${ }^{7}$ where varied traditional uses

4 Christina P Wong and others, 'Linking ecosystem characteristics to final ecosystem services for public policy’ (2015) 18:1 Ecology Letters 108.

5 Ibid.

6 BE Scott and others, 'The Cooperative Participatory Evaluation of Renewable Technologies on Ecosystem Services (CORPORATEs)' 2016 Scottish Marine and Freshwater Science Vol 7 No 1 .

7 Inch Cape; Neart na Gaoithe and SeaGreen Alpha and Bravo. 
and interests coincide in space and time, including proposed offshore windfarms and recently designated Marine Protected Areas (MPAs). ${ }^{8}$

This chapter, which is in four parts, is a detailed examination of the legal and policy position to support the development of this decision support process and in particular the ecosystem approach to marine planning in Scotland. The next part sets out the legal and policy context for the research project. It addresses the question as to what law and policy is required to implement MSP in Scotland and considers in detail how the law and policy are used to enshrine the use of the ecosystem approach in MSP. It also describes the real life MRE applications upon which this project was based. The chapter then moves on to discuss the wider CORPORATES project, explaining how the participatory tool was developed by the interdisciplinary team and then tested through stakeholder workshops. The final part discusses in detail the role of law in the project. Analysis reveals that the existing regulatory framework in Scotland, although complex, is appropriate and can be effective in implementing the ecosystem approach in MSP. However, the research showed that in order to be effective, the law and policy had to be fully embedded within the participatory processes to enable an ecosystem approach in MSP to be implemented. The research also provided methods and ways of doing this. It has been shown that this active use of law and policy can be pivotal to the implementation of the ecosystem approach in Scotland. It is considered that these conclusions and lessons can be used elsewhere to implement the ecosystem approach as part of MSP both at regional and international scales.

Legislative and Regulatory Framework

As it happens, Scotland can be regarded as being globally at the forefront of the development of a marine spatial planning regime. This is evidenced by the production in recent years of a significant number of legal and policy instruments,

8 Inch Cape, $15^{-22}$ kilometres east of the Angus coastline on the east coast of Scotland, UK comprising of up to 110 wind turbine generators with a gross electrical output capacity of 784 MW. Neart na Gaoithe 15.5 kilometres to the east of Fife Ness in the Firth of Forth on the east coast of Scotland comprising of up to 75 wind turbine generators of not more than $6 \mathrm{MW}$ each with a gross electrical output capacity $450 \mathrm{MW}$. SeaGreen Alpha 27 kilometres east of the Angus coastline and comprising of not more than 75 three-bladed horizontal axis wind turbine generators and a permitted generating capacity not exceeding $525 \mathrm{MW}$. SeaGreen Bravo 38 kilometres east of the Angus coastline comprising of not more than 75 three-bladed horizontal axis wind turbine generators and a permitted generating capacity not exceeding 525 MW. The first MPAS of the Scottish MPA Network were designated on 24th July 2014 in the North Sea. 
most particularly the Scottish National Marine Plan of 2015. ${ }^{9}$ The development of a legislative and regulatory framework to introduce new concepts, such as MSP and complex processes like the ecosystem approach, requires detailed explanation. This was the starting point for the lawyers in the project and also for the discussion in this chapter. This review of the relevant law looked at the source of the legal authority, as well as what the law actually required. It was also noted that there is an intricate interrelationship between MSP legislation and policy, which together underpin the requirement for an ecosystem approach in MSP in Scotland. This section starts, therefore, by setting out the wider constitutional and legislative issues. It then considers the law and the policy that implemented marine planning, before discussing the legal framework for implementing the ecosystem approach.

The Development of MSP and Wider Constitutional and Legislative Issues in Scotland

In Scotland, the development of the legal and policy framework for MSP and the ecosystem approach is evolving within the context of complex devolved arrangements from the UK government. ${ }^{10}$ In terms of law, the geographical extent/scope of Scotland includes so much of the internal waters and territorial sea of the United Kingdom as are adjacent to Scotland'.11 In terms of transfer of power from the UK to the Scottish government the basic premise of Scottish devolution is that only matters reserved to the UK government are set out in the legislation. If a matter is not reserved then it is devolved. ${ }^{12}$ This means that the sea from 12 nautical miles $(\mathrm{nm})$ to the edge of the exclusive economic zone (EEZ) and the seabed of the continental shelf is part of the UK. The development and implementation of MSP presents challenges within this complex regulatory framework, as in the years since devolution, an intricate web of powers and legislation governing activities within the marine environment has developed in Scotland. Under the devolution arrangements some powers have been executively devolved, which enables the Scottish Ministers to exercise statutory functions within their devolved competence. These statutory functions are specified in legislation governing different activities. For example, the Marine and Coastal Access Act 2009 governs the process of

Marine Scotland, Scotland's National Marine Plan: A Single Framework for Managing Our Seas, The Scottish Government (March 2015).

10 The Scotland Act 1998 c.46 substantially amended by inter alia the Scotland Act 2012 c.11 and the Scotland Act 2016 c.11. The European Union (Withdrawal) Bill 2017-18 (HL Bill 79) is expected to change these devolution arrangements further.

11 Scotland Act 1998 c.46 s.126 (1).

12 Scotland Act 1998 c. 46 Schedule 5 Part I General Reservations, Part II Specific Reservations. 
marine planning in the Scottish offshore area (i.e. $12 \mathrm{~nm}$ - the edge of the continental shelf). ${ }^{13}$ This is a prime example of executive devolution. The Scottish Parliament, however, has no authority to change the legislation. In regard to marine spatial planning, in Scottish waters, this means that there are two pieces of relevant legislation: the Marine and Coastal Access Act 2009 and the Marine (Scotland) Act 2010. The former enables the Scottish Ministers to create a marine plan for the offshore area adjacent to Scotland, ${ }^{14}$ while the latter obliges them to create a marine plan for the territorial sea adjacent to Scotland. ${ }^{15}$ Notwithstanding the complexity of the constitutional and legislative arrangements the legislation enables a workable solution in terms of creating a legislative and regulatory framework for MSP. This has facilitated the adoption of Scotland's National Marine Plan which extends to the EEz.

2.1.1 Implementing Marine Planning in the UK and Scotland MSP in UK waters, including Scotland, is characterised by the creation of marine spatial plans within an overarching policy framework of the 2011 Marine Policy Statement (see below). ${ }^{16}$ It should be noted that there is no separate MSP 'planning permission' regime, but decisions by public authorities must be taken in accordance with the appropriate marine spatial plans, unless relevant considerations indicate otherwise. ${ }^{17}$ Marine planning in Scotland is, therefore, a process of making decisions for the marine environment in the context of marine policies and plans. Planning is implemented through marine licencing decisions, which must have regard to the appropriate marine plans.

Decisions under the Scottish MSP regime require consideration of certain criteria set down by the legislation, including that decisions should be taken in the context of sustainable development and the ecosystem approach. ${ }^{18}$ If the decision is not in conformity with the plan, the authorities must state their reasons for this. ${ }^{19}$ When considering marine license applications, the Scottish Ministers must 'have regard to the need to (i) protect the environment, (ii) protect human health, [and] (iii) prevent interference with legitimate uses of

\footnotetext{
13 Marine and Coastal Access Act 2009 c.23 Part 3 ss.49-54 read with schedule 6 and s. 322.

14 Marine and Coastal Access Act 2009 c.23 s.51.

15 Marine (Scotland) Act 2010 asp 5 s.5 (1).

16 Marine and Coastal Access Act 2009 c.23 ss 44-48 and schedule 5 .

17 Marine (Scotland) Act 2010 asp 5 S.15(1) and Marine and Coastal Access Act 2009 c.23 S.58 (1).

18 Marine (Scotland) Act 2010 asp 5 s.3; and Marine and Coastal Access Act 2009 c.23 s.58 (1).

19 Marine (Scotland) Act 2010 asp 5 s.15 (2) and Marine and Coastal Access Act 2009 c.23 S.58 (2).
} 
the sea: ${ }^{20}$ Decisions must also be made in accordance with the Marine Policy Statement (MPS) which provides the policy framework for the marine planning systems, including the system being developed in Scotland. ${ }^{21}$

\subsubsection{Marine Policy Statement (M PS)}

The Marine Policy Statement (MPS) produced in 2011 was jointly adopted by the relevant 'home nations' Ministers for all parts of the United Kingdom. ${ }^{22}$ It is not a spatial document but provides the foundation on which spatial documents (plans) are being developed. The M PS states that marine planning in the United Kingdom will:

- achieve integration between different objectives;

- recognize the demand for use of our seas and the resulting pressures on them will continue to increase;

- manage competing demands on the marine area, taking an ecosystem approach;

- enable the co-existence of compatible activities wherever possible; and

- integrate with terrestrial planning. ${ }^{23}$

It is divided into five parts: an introductory context, three chapters, and a conclusion. Chapter one 'sets out the role of the Marine Policy Statement (M PS) within the wider marine planning system and its interaction with existing planning regimes. ${ }^{24}$ Chapter two identifies the 'high level approach to marine planning' adopted within the UK and sets out the 'general principles for decision making that will contribute to achieving' the vision. ${ }^{25}$ It does this by identifying 'the framework for environmental, social and economic considerations that need to be taken into account in marine planning. ${ }^{26}$ Chapter three is a collation of policy objectives for key marine activities within the UK. It also provides guidance for planners and decision makers 'on the pressures and impacts associated with these activities, which will need to be considered when planning for and permitting development in the UK marine area'. ${ }^{27}$

\footnotetext{
20 Marine (Scotland) Act 2010 asp 5 s.27(1)(a); and Marine and Coastal Access Act 2009 c.23 s.69(1).

21 Marine and Coastal Access Act 2009 c.23 s.58 (5) and (6).

22 HM Government, Northern Ireland Executive, Scottish Government, Welsh Assembly Government, Marine Policy Statement (The Stationary Office 2011).

23 Ibid., 4.

24 HM Government (2011) (n 22) 7.

25 HM Government (2011) (n 22) 10.

26 Ibid.

27 HM Government (2011) (n 22) 26.
} 


\subsubsection{Scotland's National Marine Plan}

Scotland's National Marine Plan (SNMP) was published in March $2015^{28}$ after an extensive period of consultation. ${ }^{29}$ It follows the general guidance established by the MPS, but goes further in that it sets out Scotland-wide high level policy objectives, including spatial guidance for all aspects of the seas and the marine environment. Covering both the inshore $(0-12 \mathrm{~nm})$ and offshore $(12-200 \mathrm{~nm})$ marine environment, the plan aims to provide a comprehensive overarching framework for all marine activity. It is intended to enable sustainable development and use of the marine area in a way that will protect and enhance the marine environment, whilst promoting both existing and emerging industries. ${ }^{30}$

The plan has 16 chapters and 3 appendices. The appendices pinpoint:

1. ecosystem goods and services;

2. strategic objectives, which include the descriptors for good environmental status (GES) and the High Level Marine objectives contained in the MPS;

3. a summary of assessment information from Scotland's Marine Atlas, which informed development of the plan.

Chapters 1 to 3 provide the context for the development of the marine plan and identify the vision, objectives and approach to the policies. Chapter 4 sets out twenty-one general planning policies to guide decision makers which 'apply to all development and use. ${ }^{31}$ Key general policies are illustrated below and are 'supplemented' by the sectoral chapters which are set out in chapters 6 to 16 of the plan. Chapter 5 offers an overview for the sectoral chapters.

The general planning policies include

1. A presumption in favour of sustainable development consistent with the plan.

2. Sustainable development to provide economic benefits for Scotland consistent with the plan.

3. Sustainable development to provide social benefits for Scotland consistent with the plan.

4. Co-existence of activities consistent with the plan.

28 Marine Scotland (2015) (n 9).

29 Rural Affairs, Climate Change and Environment Committee, Scottish Parliament, 2nd Report 2015 (Session 4) Report on Scotland's Marine Plan (Scottish Parliament, 30 January 2015).

$30 \quad$ Marine Scotland (2015) (n 9) 15-16.

31 Marine Scotland (2015) (n 9) 15. 
5. Marine planners and decision makers required to act in the way best calculated to mitigate, and adapt to, climate change. ${ }^{32}$

6. Historic environments should be protected in proportion to their significance. ${ }^{33}$

Having set out in overview the relevant law and policy to implement MSP in Scotland, this part now considers in detail what the law requires in relation to the ecosystem approach and how this relates to the policy.

\subsection{The Legal Framework for Implementing the Ecosystem Approach}

There are three requirements in the Marine and Coastal Access Act 2009 (the 2009 Act) which directly relate to the implementation of the ecosystem approach to MSP in Scotland. First, the 2009 Act requires that a Marine Policy Statement (MPS) be prepared and adopted. ${ }^{34}$ As noted above, the MPS is a framework for marine planning in UK waters. It is this policy document which requires an ecosystem approach to marine planning. The 2009 Act also requires that all marine plans must be in conformity with the MPS, unless relevant considerations indicate otherwise. ${ }^{35}$ Together the MPS and Marine plans are defined as marine policy documents. ${ }^{36}$ Finally, the 2009 Act requires that, in taking decisions in relation to UK marine waters, public authorities must do so in accordance with the appropriate marine policy documents, unless relevant considerations indicate otherwise. ${ }^{37}$

The UK legislation, therefore, requires that an overarching framework policy be created for all UK waters. A guiding principle of this policy is that an ecosystem approach must be adopted for all UK marine planning. This is achieved by the legislation requiring that the MPS, which promotes the ecosystem approach, must be followed in all other marine plans and policy documents. The ecosystem approach is therefore cascaded down from the MPS to other marine plans. The legislation has enshrined a plan-led approach which expects that the marine plans and the MPS will be followed in making decisions. This gives primacy to the plans and therefore to the ecosystem approach.

There are also three requirements in the Marine (Scotland) Act 2010 which directly relate to the implementation of the ecosystem approach to MSP in Scotland. First, Scottish Ministers and public authorities much act in a 'way best calculated to further the achievement of sustainable development,

\footnotetext{
$32 \quad$ Marine Scotland (2015) (n 9) 18.

33 Marine Scotland (2015) (n 9) 19.

34 Marine and Coastal Access Act 2009 c.23 ss.44-48 read with schedule 5 .

35 Marine and Coastal Access Act 2009 c.23 s.51 (6).

$36 \quad$ Marine and Coastal Access Act 2009 c.23 s.59.

37 Marine and Coastal Access Act 2009 c.23 s.58 (1).
} 
including the protection and, where appropriate, enhancement of the health of that area, so far as is consistent with the proper exercise of that function. ${ }^{38}$ Second, the process of preparing and adopting a Marine Plan includes an assessment of the current condition of the marine area and a summary of pressures and impacts. Moreover, it requires the Scottish Ministers to set economic, social and marine ecosystem objectives. ${ }^{39}$ Finally, decisions by Scottish Ministers and public authorities must be taken in accordance with the marine plans, unless relevant considerations indicate otherwise. ${ }^{40}$

The Scottish legislation, therefore, also requires a plan-led approach to marine planning. Marine Plans in Scotland must follow the MPS and therefore promote an ecosystem approach to marine planning. These plans must also be followed in decision making unless relevant considerations indicate otherwise, thereby ensuring the primacy of the plan and the primacy of the ecosystem approach. In Scotland there is also a specific duty to further the achievements of sustainable development, including the protection and, where appropriate, enhancement of the health of a particular area, so far as it is consistent with the proper exercise of that function. ${ }^{41}$ There is no definition of sustainable development within the Scottish marine planning legislation. The concept, however, is widely recognised as having 3 equal pillars: economic, environmental, and social. The ecosystem approach enables the environmental pillar to be actualised in policy development and decision making. In Scotland, therefore, an ecosystem approach is not only required by law, in terms of requirements relating to the MPS, but also by the duty to further the achievement of sustainable development, when exercising any function within the Scottish marine area and by the requirement to set economic, social, and marine ecosystem objectives during the marine planning process.

Having set out the requirements in law, the role of policy in implementing the ecosystem approach will be considered in detail. First, however, it is appropriate to consider the relationship between law and policy. It has been pointed out that one of the keys to understanding the (terrestrial planning) system is recognising the differences between law, which must be observed at all times, and policy, which is not binding with departures permitted in individual cases. ${ }^{42}$ In the marine environment, the law provides the basis for

\footnotetext{
38 Marine (Scotland) Act 2010 asp 5 s.3.

39 Marine (Scotland) Act 2010 asp 5 s.5.

$40 \quad$ Marine (Scotland) Act 2010 asp 5 s.15.

41 Marine (Scotland) Act 2010 asp 5 s.3.

42 Neil Collar, Planning (4th ed. W. Green 2016).
} 
decision making as part of the marine spatial planning regime and this enables the incorporation of policy into decisions made in the marine environment. The law requires policies to be developed (e.g. publication of the National Marine Plan is a duty of the Scottish Ministers). Such plans and policies provide numerous benefits. First, they provide certainty for developers. Second, they facilitate implementing conservation obligations. Third, they provide opportunities for public involvement and participation. Fourth, they promote consistent decision making. Conversely, it is essential to note that what the law seeks to discourage is the blind unthinking application of policy. It does this by providing the decision maker with wide discretionary powers to depart from the plan, when relevant considerations indicate that this is required. ${ }^{43}$ This facilitates an adaptive approach to decision making within the marine environment. The weight attached to the policies is for the decision maker to determine, however, interpretation of these policies is a matter of law. ${ }^{44}$

The Marine Policy Statement (MPS), as discussed above, is a comprehensive policy framework for implementing marine planning. It provides the highlevel policy context within which national and subnational marine plans will be developed. In so doing it also sets the direction for marine licensing and other relevant authorisation systems. It specifically states that the process of marine planning will manage competing demands in the marine area, taking an ecosystem approach. ${ }^{45}$ It provides a practical interpretation of the ecosystem approach by reference to Regulation 5 of the Marine Strategy Regulations 2010. ${ }^{46}$ These Regulations transpose the requirements of the EU Marine Strategy Framework Directive into UK law. The definition in the MPS is as follows: '[a]n ecosystem based approach to the management of human activities means an approach which ensures that the collective pressure of human activities is kept within the levels compatible with the achievement of good environmental status; that does not compromise the capacity of marine ecosystems to respond to human induced changes; and that enables the sustainable use of marine goods and services. ${ }^{\prime} 7$ The MPs, therefore, requires that an ecosystem approach be adopted for marine planning - both plan making and decision making. Although the MPS is a policy document, the process of decision making, which requires that the MPS (and therefore the ecosystem

\footnotetext{
43 Marine (Scotland) Act 2010 asp 5 s.15 (1) and Marine and Coastal Access Act 2009 c.23 S.58 (1).

44 Millar Homes Ltd v Scottish Ministers [2015] CSIH 20.

45 HM Government (2011) (n 22) 4.

46 The Marine Strategy Regulations 2010 S.I. 2010/1627.

47 HM Government (2011) (n 22) 4.
} 
approach) is taken into account, is set down in the legislation and therefore must be followed.

Scotland's Marine Plan sets out the vision, objective and approach to policies. Referencing the definition of the ecosystem approach identified in the MPS, Scotland's Marine Plan states that the plan 'promotes an ecosystem approach by putting the marine environment at the heart of the planning process to promote ecosystem health, resilience to human induced change and the ability to support sustainable development and use. ${ }^{48}$ Scotland's Marine Plan, like the MPS connects 'an ecosystem based approach to the management of human activities. ${ }^{49}$

For example, it states that:

The ecosystem approach is reflected in the adoption as strategic objectives of the 11 Descriptors of Good Environmental Status (Annex B), set out in the Marine Strategy Framework Directive. These 11 Descriptors represent an attempt to identify the key aspects of ecosystem structure and function, with relevant targets and indicators being set in conjunction with neighbouring states at the broad scale of the Celtic Seas and the Greater North Sea. ${ }^{50}$

\subsubsection{Regional Marine Plans}

Regional planning was always considered to be an essential part of the overall marine planning vision for Scotland. ${ }^{51}$ In May 2015 (as the research project was concluding) the boundaries for 11 marine regions were finalised. ${ }^{52} \mathrm{~A}$ regional marine plan will be created to guide and assist all decision making in these marine areas. At the time of writing, two Regional Marine Planning Partnerships have been established. ${ }^{53}$ The overall framework for implementing the ecosystem approach (set out above) applies to the development of the plans made by marine planning partnerships, ${ }^{54}$ and to the decisions that are made within the areas where regional marine plans have been created. ${ }^{55}$

\footnotetext{
48 Marine Scotland (2015) (n 9) 11 paragraph 3.4.

49 HM Government (2011) (n 22) 16-21; Marine Scotland (2015) (n 9) 12.

5o Marine Scotland (2015) (n 9) 12 paragraph 3.6.

$5^{1} \quad$ SP Bill 25 Marine (Scotland) Bill [as introduced] Policy Memorandum Session 3 (2009) para 22.

$52 \quad$ Scottish Marine Regions Order 2015 SSI 2015/193.

53 The Delegation of Functions (Regional Marine Plan for the Scottish Marine Region for the Clyde) Direction 2017, The Delegation of Functions (Regional Marine Plan for the Scottish Marine Region for Shetland) Direction 2016.

54 Marine (Scotland) Act 2010 asp 5 s.5 read with schedule 1 and s.6.

55 Marine (Scotland) Act 2010 asp 5 s.15 (4) (b) (ii).
} 


\subsubsection{Terrestrial Planning}

The existing legislative and regulatory framework in Scotland acknowledges the need for integration of the marine and terrestrial planning regimes. ${ }^{56}$ To date this has been achieved by statutory consultation, aligning plans and by an overlap of plans within the intertidal areas. ${ }^{57}$ The terrestrial planning legislation in Scotland requires its plans to contribute to sustainable development, but it falls short of requiring an ecosystem approach for town and country planning. 58

\subsubsection{MRE: the Real Life Scenarios}

The CORPORATES project used real-life cases, in the form of 4 large offshore wind farms proposed for the Firth of Forth and the Firth of Tay, in the North Sea, Scotland, UK ${ }^{59}$ (See Figure 9.1). Each of these projects was subject to a number of pre- and post-application consultations, authorisations, and licensing processes. ${ }^{60}$ The main consent for each proposal was a section $3^{6}$ application under the Electricity Act. ${ }^{61}$ This determination being made in the context of the Marine Acts, therefore requiring implementation of the ecosystem approach. ${ }^{62}$ The principal issues material to the merits of the application included the adequacy of the environmental information and the consultation undertaken to assess the impact of the development. ${ }^{63}$ After a lengthy process the decision to grant all the section 36 applications, subject to conditions, was made by the Scottish Ministers on the 1oth October 2014.

$5^{6}$ Scottish Government, The Relationship between the Statutory Land Use Planning System and Marine Planning and Licensing (Planning Circular 1/2015, June 2015).

57 Marine Scotland (2015) (n 9) 31. General policy 15 Good governance Marine and terrestrial plans should align to support marine and land-based components required by development and seek to facilitate appropriate access to the shore and sea. GEN 15.

$5^{8}$ Town and Country Planning (Scotland) Act 1997 c.8, s. 3 D and s.3E.

59 Ibid. (N8).

6o Consent under s. 36 of the Electricity Act 1989 c.29; marine licences under the Marine (Scotland) Act 2010 asp 5 and the Marine and Coastal Access Act 2009 c.23. Submission of Environmental Assessments under the Electricity (Applications for Consent) Regulations 1990, S.I.1990/455; The Electricity Works (Environmental Impact Assessment) (Scotland) Regulations 2000, S.S.I. 2000/320 (as amended) and the (as amended). Submission of Habitats Regulation Appraisal under Conservation Natural Habitats, \& c.) Regulations 1994, S.I. 1994/2716 (as amended) and the Offshore Marine Conservation (Natural Habitats, \& c.) Regulations 2007, S.I. 2007/1842.

61 Electricity Act 1989 c.29.

62 The Marine Acts consist of the Marine and Coastal Access Act 2009 c.23 and the Marine (Scotland) Act 2010 asp 5 .

63 The other principal issues were: decommissioning, economic development, renewable energy policies, consultation responses and the integrity of the European protected sites. 


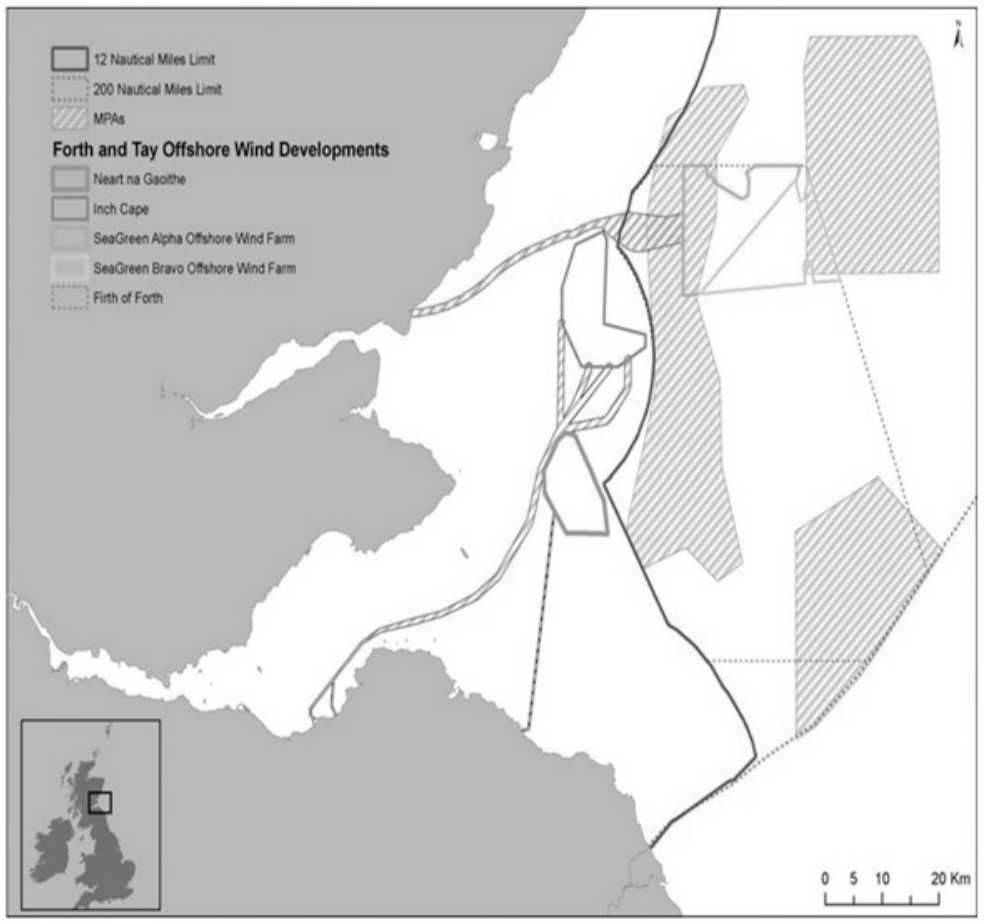

FIGURE 9.1 Windfarm proposals

SOURCE: ANDRONIKOS KAFAS

The licenses incorporate numerous conditions relating to environmental issues, including the provision of additional actions and information for further approval before commencement of work. ${ }^{64}$ These decisions were subject to a series of ultimately unsuccessful judicial review challenges. ${ }^{65}$

64 For example, submission of an Environmental Management Plan for approval from Scottish Ministers. To mitigate the impacts on environmental interests during construction and operation.

65 Royal Society for Protection of Birds, Scotland (the RSPB) $v$ The Scottish Ministers and Seagreen Energy Limited $P_{30} / 15$ (Seagreen Bravo) [2016] CsOH 105; Royal Society for Protection of Birds, Scotland (the RSPB) $v$ The Scottish Ministers and Seagreen Energy Limited $P_{31} / 15$ (Seagreen Alpha) [2016] csoH 106; Royal Society for Protection of Birds, Scotland (the RSPB) $v$ The Scottish Ministers and Neart na Gaoithe Offshore Wind Limited P29/15 [2016] CsOH 104; Royal Society for Protection of Birds, Scotland (the RSPB) $v$ The Scottish Ministers and Inch Cape Offshore Limited P28/15 [2016] CsOH 103; Royal Society for Protection of Birds, Scotland (the RSPB) $v$ The Scottish Ministers and first Inch Cape Offshore Limited and second Neart na Gaoithe Offshore Wind Limited and third Seagreen Energy Limited P28/15 [2017] CSIH 31. Following the Inner House of the Court of Sessions decision of May 2017 to overturn the 
Having provided the context in the form of the legal and regulatory framework for MSP and the ecosystem approach, as well as key details about the real-life applications for offshore windfarms in Scotland, the next part of this chapter considers the CORPORATES project in detail.

The corporates Project

\subsection{Context and Use of the 'Live' Case Studies}

The CORPORATES interdisciplinary project sought to develop a process for knowledge exchange around marine ecosystem services within the context of marine spatial planning decisions. ${ }^{66}$ An important novel aspect of the project was its use of real-life cases of proposed offshore wind farms as described above. It is important to note that although the research project process centred on 'live' decision making cases, they were chosen as a wide range of stakeholders could be identified, who could then focus attention on engaging with the participatory process during the research project workshops. It was extremely helpful to use examples that had already been through the consultation and public participation process as part of the decision making regime. The aim was not to influence the decision making in the actual cases.

decision of the Outer House which had revoked the consents granted to the developers, the RSPB applied for leave to appeal to the Supreme Court. This application was refused by the Inner House of the Court of Session on 19th July 2017. On the 17 August 2017, the RSPB applied directly to the Supreme Court for permission to appeal against the Inner House decision. See: RSPB, Casework, Forth and Tay Windfarms < $<w w . r s p b$ .org.uk/about-the-rspb/about-us/media-centre/press-releases/rspb-scotland-plans -to-appeal-offshore-wind-farm-judicial-review/> accessed 28 September 2018. The Supreme Court refused this application on 7 th November 2017 stating that 'the application does not raise an arguable point of law of general public importance which ought to be considered at this time, bearing in mind that the case has already been the subject of judicial decision and reviewed on appeal'. See: The Supreme Court, Permission to appeal decisions, The Royal Society for the Protection of Birds (RSPB) (Appellant) v The Scottish Ministers and others (Respondents) (Scotland) - UKSC 2017/0143 <www .supremecourt.uk/news/permission-to-appeal-decisions-07-november-2017.html> accessed 9 November 2017 .

66 Partners included Aberdeen University (project lead) (Biological Sciences, Geography and Law), the Scottish Association for Marine Studies, Marine Scotland Science and the James Hutton Institute. The project design and delivery was highly trans-disciplinary, involving experts with backgrounds in ecology, oceanography, marine management, policy, law, environmental psychology, anthropology and ecological economics as well as public and private sector stakeholders. 
These specific decisions and the precise process that was followed during the application procedure were part of the CORPORATES project, only insofar as they provided the location and examples for the case study areas in the Firths of Forth and Tay. The details of the individual applications were not interrogated, although the process and procedure by which the licensing applications had been made was an important context for the project. The fact that the development of the participatory process used 'live' existing applications, but only as case studies, was emphasised during both of the workshops discussed below.

\subsection{CORPORATES: Workshop 1}

The first main project task for the research team was to identify and secure an appropriate range of stakeholders who could commit to two days (some months apart) to attend the project workshops. This was successfully achieved, with participation by representatives from the marine renewable energy industry, marine regulators and advisers being brought together with representatives of fishing organisations, non-governmental organisations (NGOs), tourism operators, recreationalists and local government. The CORPORATES research team then devised appropriate activities to identify existing knowledge and quickly develop shared understandings within and across the stakeholders participating in the workshop. In the first workshop the sectoral representatives (fisheries, conservation and recreation) physically drew on hard copy maps of the project area to identify specific areas and activities of importance to their sector. These were then displayed and discussed by all participants. The sector groups then created lists of benefits derived from the mapped activities, which were compared in order to identify commonalities and differences. The main objective of the first workshop was to introduce stakeholders to the concept of Environmental Services (ES). The workshop activities facilitated stakeholders to link ES to the benefits derived by all in the case study area.

\subsection{CORPORATES: Workshop 2}

In the period between the two workshops, the research team grouped the benefits identified by the stakeholders into broader categories and linked them to three key ES for the project: fish and shellfish; climate regulation; and seascape. ${ }^{67}$ In the second workshop participants from different sectors now

67 U.K. National Ecosystem Assessment (UK NEA) Progress and Steps Towards Delivery, Cambridge: UNEP-WCMC (February 2010) <http://uknea.unep-wcmc.org/LinkClick.aspx ?fileticket $=\mathrm{LDV}_{3} \mathrm{vMdXFeY \%}{ }_{3} \mathrm{D} \&$ tabid=105 $>$ accessed 30 November 2017. 
worked together, still in small groups, to link the different categories and benefits back into the three key ES. Each mixed sector group then created their own conceptual system model (CSM) in order to explore interactions and feedback between ecological processes and associated features, benefits, and activities / actions. The development of the CSM started from ecological processes that constitute the base of the food chain, up through species and habitat diversity, to ES benefits and activities such as current fishing, future windfarm development, and MPAs, showing the links between all these aspects. Each group was facilitated by members of the CORPORATES project team in their development of the CSM. Consensus was required by the mixed sector group of stakeholders. Participants could return to reprise areas of concern and dispute within their group, but ultimately it was the ability to balance trade-offs that encouraged agreement. Once the CSM was finalised the mixed groups discussed the potential impacts of relevant law and policy developments concerning key areas, including fisheries, climate change and conservation. Finally, individual participants were invited to write out their personal opinions on possible future priorities for ES benefits and activities that would enhance the ability of a mixed group to reach consensus. The project aim was to develop a 'hands on' way of generating a shared understanding of the interlinkages among different aspects of the marine ecosystem and the benefits derived from it. Specifically, the workshop activities and shared learning objectives were to develop a tool that would enable trade-offs to be agreed through the process, which would facilitate both the approval of MREs and the development of holistic policy for the marine environment. ${ }^{68}$

\subsection{Knowledge Exchange, Shared and Institutional Learning}

The workshops were designed to draw out individual participants' information and knowledge, which then collectively enabled a group to work together to enhance awareness and to reach consensus. Initially through discussion around mutual benefits derived from ES and then by building the CSM. The shared knowledge gained through the activities within the workshops was augmented by seminars which provided learning about pertinent aspects of the project. ${ }^{69}$

68 The CORPORATES approach was tested on current and future Scottish Marine Regions planners through a workshop sponsored by the Marine Alliance for Science and technology for Scotland (MASTS) and Marine Collaboration Research Forum (MarCRF) June 2015.

69 The seminars were referred to as interludes during the workshops and in the Report the topics were: marine ecosystem function, intermediate and final ecosystem services, and law and policy. BE Scott and others (n 6) 4 and 51. 
The seminar topics were ones where it was understood that explanation by experts would enhance the overall learning experience and contribute to the ability of the group to reach consensus. The importance of understanding the role of law and its relationship to policy was one of these key areas. A seminar on the legislative and regulatory framework was included in workshop 2.

The whole process of developing the decision making framework was an active and iterative one. In relation to the legal side of the project, there were a number of actions and activities that arose as part of the development process. The benefit of a knowledge exchange project is the opportunity to share knowledge and expertise with those from a related area, but with different skills and baseline information. The questions and early conclusions by the CORPORATES project group challenged assumptions and required each speciality to present their knowledge in a way that was suitable for an interdisciplinary group and also to most effectively contribute to the project. The CORPORATES project group as a whole (researchers and stakeholders) had research experience in marine matters and/or in participatory processes and/ or ES. In relation to law, there was a variety of awareness of the relevant MSP and ecosystem approach law and policy, with some participants possessing intricate knowledge of policy development or specialist knowledge in certain areas (e.g. fisheries or public participation). This enabled elucidation of the way decisions are made, which in turn contributed to the development of the decision making tool. Challenges encountered included comprehension of the relationship between Scottish law, EU law, and international law. In particular, explanation of the legal duties of applicants, decision makers and others relating to public participation, particularly the wider legal context for public engagement beyond the MSP legislation, was necessary to enable development of the participatory tool. The key finding from this part of the research project was that there is real value in experts explaining the law. The MSP statutory provisions are complex and multi-layered due to both the wider international and EU context and the UK/Scotland devolution arrangements. They also relate to a process of decision making which is intricately linked to policy.

During the research project, the identification of activities and benefits by the stakeholders broadened the scope of laws that were reviewed. It became clear that relevant laws extended far beyond the legislative and regulatory framework for MSP and the ecosystem approach. For example, to enable activities such as bird watching or recreational fishing, parking facilities are 


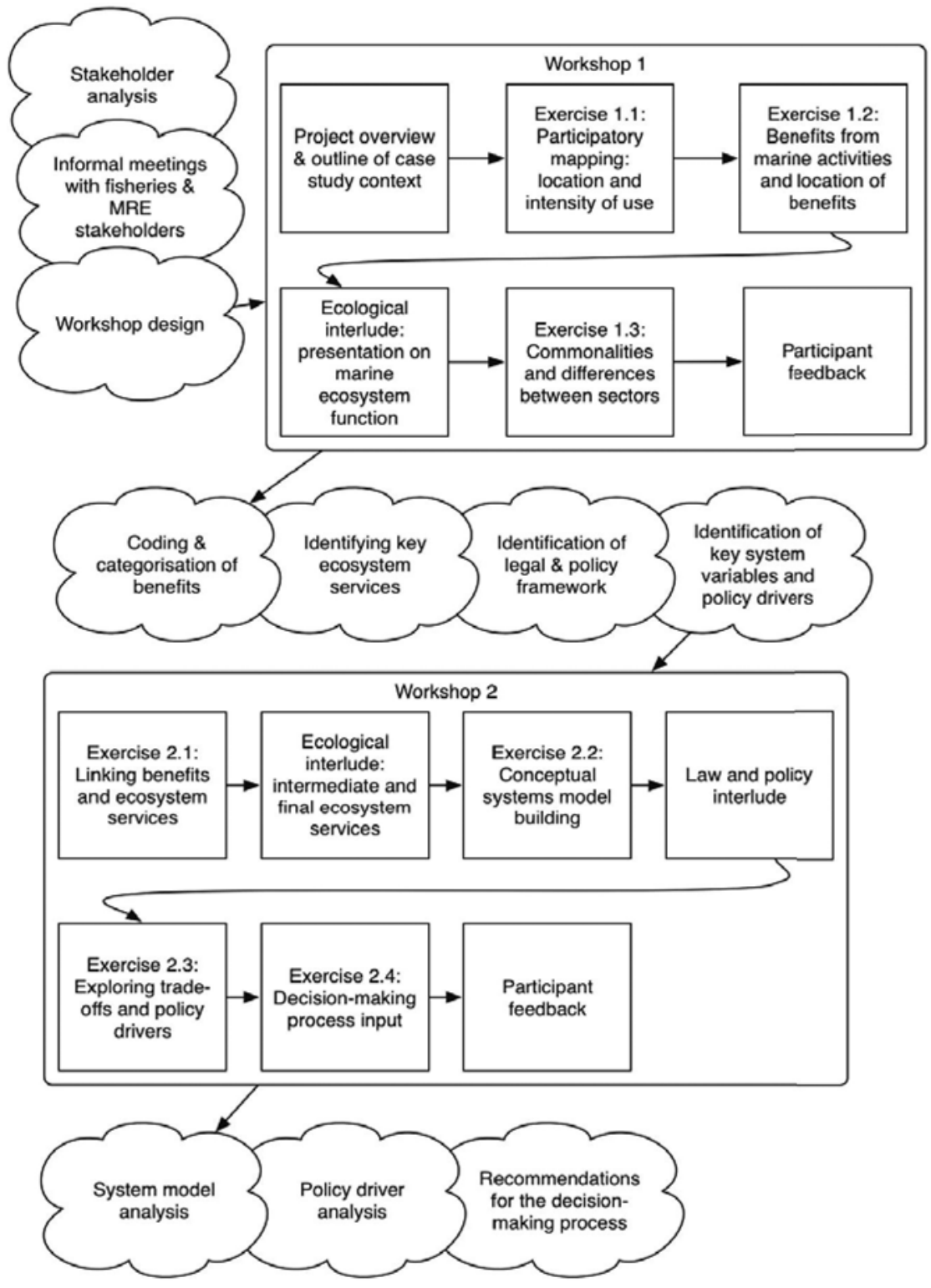

FIGURE 9.2 CORPORATES methodology SOURCE: ANDRONIKOS KAFAS 
required, and access to land is needed. ${ }^{70}$ Furthermore, these activities must be carried out with regard to the species concerned. ${ }^{71}$

After the first workshop, three main areas of law were identified that would tie in the learning around ES and assist in the creation of an appropriate and effective CSM: fishing; offshore wind; and the recreational use of the coastal area through access to land/sea. The laws governing these activities were, therefore, researched and connected with MSP and the ecosystem approach. A briefing report was prepared for the CORPORATES project group with large scale mind maps used to provide a visual representation of the extent and range of primary and secondary legislation in these areas. ${ }^{72}$ The wider legal context was then considered in detail by the project team in the preparatory workshop meetings, and as can be seen in Figure 9.2. The provision of this legal research enhanced the overall knowledge exchange and enabled an informed discussion about the effects of the implementation of MSP and the ecosystem approach on other activities during workshop 2.

\subsection{Feedback and Outcomes from the Workshops}

Feedback from the stakeholders who attended workshops and tested the participatory process completed the research. This feedback highlighted the benefits of cooperative learning and discussion, particularly across sectors, within a marine ecosystem services approach in marine planning processes. Overall, the feedback concluded that the method developed was effective for a number of reasons. First, it enabled the co-production of information between researchers from many disciplines and researchers from a wide variety of sectors. Second, the method effectively embedded the use of law and policy in the

$70 \quad$ For example, under s.32 of the Road Traffic Regulation Act 1984 c.27 local authorities may provide parking facilities. Local authorities are defined under the Road Traffic Regulation Act 1984 by reference to the Local Government etc. (Scotland) Act 1994 c.39. The Local Government etc (Scotland) Act 1994 constituted local authorities in Scotland and defines their powers and duties. In Scotland, the Land Reform (Scotland) Act 2003 asp 2 provides individuals with a statutory right of responsible access to land for various purposes including recreational and educational uses.

$71 \quad$ For example, all wild birds are protected under the Wildlife and Countryside Act 1981 c.69 [1981 Act] as amended by the Nature Conservation (Scotland) Act 2004 asp 6 and the Wildlife and Natural Environment (Scotland) Act 2011 asp 6. Under s.1 of the 1981 Act it is an offence to intentionally or recklessly disturb or harass specific species of birds, especially when nesting or close to a nest, as set out in schedule 1 and $1 \mathrm{~A}$ of the Act. However, licenses granted by Scottish Natural Heritage may be issued upon receipt of an application for specific purposes including for birdwatchers who wish to take photographs close to nesting, breeding or nursing birds.

BE Scott and others (n 6) 32-35. 
process. Third, it helped achieve positive early engagement between sectors by identifying shared benefits. Fourth, the process was effective in going beyond economic importance by incorporating non-monetary values in MSP, thereby making trade-offs between policy options more transparent when linking benefits to cultural wellbeing services. Finally, the process was effective because it succeeded in providing two way active engagement; activities enabled stakeholders to engage and contribute local knowledge, as well as to identify evidence gaps in areas for policy development. Having outlined the questions the project sought to address in the creation of a tool to enhance decision making as a participatory process with a focus on $\mathrm{ES},{ }^{73}$ and the legal framework in which the project was carried out, the next part of the chapter analyses the role of law in the development and implementation of this participatory tool. This will enable conclusions to be drawn about the effectiveness of the existing regulatory framework for MSP and the need to embed law within the participatory processes to fully develop an ecosystem approach to MSP in Scotland and elsewhere.

\section{Reflection on the Implementation of the Ecosystem Approach}

\subsection{Discussion}

The work of the CORPORATES project adopted two methodological approaches. The first involved an examination of how the law functions in relation to MSP and the implementation of the ecosystem approach in Scotland. As this chapter has shown, there are complex layers of relevant laws which were discussed in detail during the conduct of the project. This examination of the law facilitated the second methodological approach: the role of 'institutional learning. ${ }^{74}$ Both the CORPORATES team and the stakeholder participants learned about the role of law in the participatory process. This institutional learning influenced both the design of the process (activities within the workshops) and the conclusions (outcomes) from the workshops.

The underpinning fundamental issue was the need for a clear understanding of why and how MSP was implemented in law and policy, as well as how it was supported through the legislative and regulatory framework. There was a real challenge in ensuring that the complexity of the legislative and regulatory framework was appropriately understood, but this was essential in order to

73 BE Scott and others (n 6) discussed the project as a whole.

74 Olivia Woolley, Ecological Governance Reappraising law's Role in protecting Ecosystem Functionality (Cambridge University Press, 2014) 219-220. 
move on to the institutional learning element of the project. Developing this understanding involved a two way process of knowledge exchange which, inter alia, clarified for the lawyers, as well as the other participants, issues around use of terminology; the complexity of the relationship between law and policy and the much wider legal framework within which the MSP and ecosystem approach regime operated. A number of specific issues arose out of the institutional learning approach, relating to law and policy and these are discussed next.

The first aspect, the institutional learning addressed, was an early assumption by some in the CORPORATES project group that new laws were required to enable the effective implementation of the ecosystem approach in marine decision making in Scotland. It was assumed that once the participatory tool, which focused on ES, was created and tested, an outcome from the project would be a recommendation about legislative changes. It was a strongly held belief that the existing legal framework was insufficient for the process developed through the workshops to be employed appropriately as a means of focusing on environmental issues. Institutional learning by the project partners about the existing decision making process, and the requirements in relation to sustainable development and the ecosystem approach, resulted in a shift in thinking by members of the CORPORATES project group. It was recognised that the existing legislative and regulatory framework provided appropriate support for the decision making process. The anticipated outcome of a recommendation for legislative change was, therefore, not a conclusion of the research. Instead, a key conclusion was that the existing law and policy supported implementation of the ecosystem approach. In order to really be effective, however, the law needed to be fully embedded into the participatory process.

The second element of institutional learning relating to law and policy was the amount and level of detailed explanation that was required for this project to operate effectively. This is perhaps not a surprise given, as noted above, that the legal and policy framework that emerged from the research was highly complex. Nevertheless, the general awareness that most members of the CORPORATES group had of the MSP laws was almost a barrier to full understanding, as assumptions were made about the process of MSP and concerns were raised about the effectiveness of the existing laws. It was the very complexity of the laws that required them to be unpicked and explained. The conclusion to this aspect of institutional learning, is that it is incumbent on lawyers and others with legal expertise, to explain effectively the legislative and regulatory processes for MSP and the ecosystem approach. This requires there to be a close working relationship between lawyers, scientists and 
policy makers as part of an institutional learning process to deliver MSP. In Scotland this should be an ongoing process as the Marine Planning Partnerships prepare and implement Regional Marine plans for all the seas and coasts of Scotland.

The third element of institutional learning was underestimating the complexity related to the vast range and extent of law and policy relevant to the creation of the legal framework for MSP. This expanding of the range of law reviewed as part of the project was a direct result of the activities and benefits identified by stakeholder participants. After workshop 1 it was recognised that a more extensive legal landscape was required. Relevant law had to be identified and examined and its relationship to the project process analysed. It was clear that an understanding of a range of laws was important to achieve effective development of the project. In particular it was required to ensure 'buy in' from participants and to create a credible and effective csm. The laws relevant to fishing, offshore wind and the recreational use of the coastal area through access to land/sea were, therefore, discussed in detail. It was demonstrated that the law governing these activities was connected with the MSP law and policy framework. ${ }^{75}$ This provided the participants with a solid understanding of the interconnectedness of multiple laws and policies beyond the strict interpretation of MSP and enhanced the ability of the group as a whole to implement the ES balancing tool. In particular, it emphasised that the legal framework for balancing ecosystem services in the decision making process in the marine environment is complex, spanning multiple sectors informed and regulated by a wide variety of policies and laws.

Evolving from this wider legal and policy framework was a developing awareness throughout the project that the interconnectedness of land and sea was also integral to ensuring that the decision making tool was viable. Making the connection in law and policy across the land-sea divide, greatly expanded the relevant legal and policy framework. It was clearly not possible to research and explain all the relevant law and policy documents, but the process of developing mind maps which included a range of relevant topics, greatly contributed to understanding the environmental issues and assisted in working through how the trade-offs might operate in practice. It was, therefore, concluded that although MSP itself is often regarded as a holistic process, really effective planning and decision making in the marine environment requires a comprehensive context beyond MSP legislation and policy in which to make effective decisions. 
The final aspect that the institutional learning addressed was the use of the words of 'law' and 'policy' interchangeably by CORPORATES participants. The need both to disentangle this and to explain the relationship between law and policy in marine decision making and the ecosystem approach was recognised as extremely important. It is undoubtedly a tricky relationship to grasp and one that in terms of the understanding and awareness of the CORPORATES project group as a whole had been underestimated by the lawyers and authors of this chapter. The final conclusion relating to institutional learning is that it is essential that the role of law and policy in MSP and the ecosystem approach is fully explained and understood by all involved.

\subsection{Lessons for the Implementation of MSP and the Ecosystem Approach}

The CORPORATES project and the analysis in this chapter reveal that the existing regulatory framework in Scotland, although complex can support the ecosystem approach in MSP. The research revealed, however, that in order to be effective, the law and policy had to be fully embedded within the participatory processes. The CORPORATES project research provided methods and ways of achieving this. It is considered that these lessons can be used elsewhere to implement the ecosystem approach; both as part of MSP plan making and the decision making processes. The following discussion applies these lessons to contexts beyond Scotland.

Legislative and regulatory changes are being developed to support MSP in many jurisdictions. The role of the lawyer is particularly important not only in creating that law, but also in enabling its effective implementation. It is essential that lawyers work with interdisciplinary teams to develop these new MSP plans and decision making processes and to ensure that they are appropriate for the areas in which they are located taking full account of the areas' particular challenges, conflicts, and opportunities. Any new MSP law will be grafted into a spectrum of other laws relevant for either or both oceans and terrestrial areas. It is important that a path be found through these laws so that MSP and the implementation of the ecosystem approach can be executed in a way that is reflective of the wider regulatory landscape. Integral to most MSP systems is an understanding of the relationship between the legal process and the role of policy within that. MSP is often not 'black letter' law; rather it provides a pivotal role for policy in the form of marine plans. These plans are integral to MSP and to its application to marine areas worldwide. It is essential, however, that the roles of law and policy in the process is fully understood in new MSP procedures. In particular, in many regimes the law will allow an element of discretion, and, therefore, the plan does not have to be automatically or blindly 
followed. Globally, marine policy and marine plans will be increasingly important, but decision making processes must take into account the most relevant and up-to-date information to support the implementation of an ecosystem approach. This may mean departing from plans in appropriate circumstances. Utilising the participatory tool created for the CORPORATES project can assist with this complex form of decision making, by enabling consensus through a detailed process. The conclusion summarises the decision making support tool. This highlights conclusions on its value in MSP decision making and the ecosystem approach.

The CORPORATES project exercise was to create a participatory decision making process around ES. As part of that, a detailed MSP legal and policy framework was created, including a wide range of marine and land laws and policies. Once developed it was revealed that this was highly complex and the focus was thus on showing the interconnectedness of the legislative and regulatory regime. Unpacking this framework to draw connections and links as well as highlighting how MSP and the ecosystem approach enabled consensus to be built, meant that although the laws and policies were perceived as complex, when taken together, they were in fact well suited to promoting MSP. The CORPORATES project relied on full engagement by a cross-section of stakeholders, who brought a range of knowledge and experience to the process. Their expertise was utilised in the workshop activities, which built on each other, to develop shared and institutional learning aimed at enhancing the understanding of the group as a whole and at encouraging informed discussion. The CORPORATES project team developed the outcomes of workshop 1 with a view to creating a structured framework for the interdisciplinary groups to develop the CSM on the basis of consensus. The decision making tool as devised by the CORPORATES process requires active participation by the stakeholders which was essential for the implementation of the ecosystem approach. Feedback from the workshop participants indicated that the process would be most effective at an early stage in regulatory decision making. It also concluded that the CORPORATES process could be developed as an integral part of the creation of marine plans and that it could be expanded to wider groups of stakeholders and local communities, resulting in extended engagement and learning processes. This would develop shared knowledge and understanding capable of making truly well informed and effective contributions to 
the development of detailed marine plans for Scotland and elsewhere. The ecosystem approach would be integral to such marine plans and it would enhance the implementation of MSP through adaptive management for all marine environments.

\section{Table of Authorities}

\section{Cases}

Martin $v$ Most [2010] UKSC 40.

Millar Homes Ltd $v$ Scottish Ministers [2015] CSIH 20.

City of Edinburgh Council $v$ Secretary of State for Scotland 1997 SCLR 1112.

Royal Society for Protection of Birds, Scotland (the RSPB) $v$ The Scottish Ministers and Seagreen Energy Limited P30/15 (Seagreen Bravo) [2016] csoH 105.

Royal Society for Protection of Birds, Scotland (the RSPB) $v$ The Scottish Ministers and Seagreen Energy Limited P31/15 (Seagreen Alpha) [2016] csoH 106.

Royal Society for Protection of Birds, Scotland (the RSPB) $v$ The Scottish Ministers and Neart na Gaoithe Offshore Wind Limited P29/15 [2016] CsOH 104.

Royal Society for Protection of Birds, Scotland (the RSPB) $v$ The Scottish Ministers and Inch Cape Offshore Limited P28/15 [2016] CsOH 103.

Royal Society for Protection of Birds, Scotland (the RSPB) $v$ The Scottish Ministers and first Inch Cape Offshore Limited and second Neart na Gaoithe Offshore Wind Limited and third Seagreen Energy Limited P28/15 [2017] CSIH 31.

\section{Legislation}

European

Directive 2008/56/EC of the European Parliament and of the Council of 17 June 2008 establishing a framework for community action in the field of marine environmental policy (Marine Strategy Framework Directive) [2008] OJ L164/19.

Directive 2014/89/EU of the European Parliament and of the Council of 23 July 2014 establishing a framework for marine spatial planning [2014] OJ L257/135.

Directive 2017/845/EU of 17 May 2017 amending Directive 2008/56/EC of the European Parliament and of the Council as regards the indicative lists of elements to be taken into account for the preparation of marine strategies [2017] OJ L125/27.

\section{UK and Scottish Statutes}

Electricity Act 1989 c.29

The Environmental Assessment (Scotland) Act 2005 asp 15

Fishery Limits Act 1976 c.86 
Land Reform (Scotland) Act 2003 asp 2

The Local Government etc. (Scotland) Act 1994 c.39

Marine and Coastal Access Act 2009 c.23

Marine (Scotland) Act 2010 asp 5

Nature Conservation (Scotland) Act 2004 asp 6

The Planning etc. (Scotland) Act 2006 asp 17

Road Traffic Regulation Act 1984 c.27

Scotland Act 1998 c.46

Scotland Act 2012 c.11

Scotland Act 2016 c.11

The Town and Country Planning (Scotland) Act 1997 c.8

Wildlife and Countryside Act 1981 c.69

Wildlife and Natural Environment (Scotland) Act 2011 asp 6

\section{Statutory Instruments}

Conservation (Natural Habitats, \& c.) Regulations 1994, S.I. 1994/2716.

Conservation (Natural Habitats, \&c.) Amendment (Scotland) Regulations 2004, S.S.I. 2004/475.

Conservation (Natural Habitats, \&c.) Amendment (Scotland) Regulations 2007, S.S.I. $2007 / 80$.

Conservation (Natural Habitats, \&c.) Amendment (No. 2) (Scotland) Regulations 2007, S.S.I. $2007 / 349$.

Conservation (Natural Habitats, \&c.) Amendment (Scotland) Regulations 2008, S.S.I. $2008 / 17$.

Conservation (Natural Habitats, \&c.) Amendment (No. 2) (Scotland) Regulations 2008, S.S.I. $2008 / 425$.

The Delegation of Functions (Regional Marine Plan for the Scottish Marine Region for Shetland) Direction 2016.

The Delegation of Functions (Regional Marine Plan for the Scottish Marine Region for the Clyde) Direction 2017.

Electricity (Applications for Consent) Regulations 1990, S.I. 1990/455.

The Electricity Works (Environmental Impact Assessment) (Scotland) Regulations 2000 , S.S.I. $2000 / 320$.

The Electricity Works (Environmental Impact Assessment) (Scotland) Amendment Regulations 2008, S.S.I. 2008/246.

The Electricity Works (Environmental Impact Assessment) (Scotland) Regulations 2017, S.S.I. 2017/101.

The Marine Strategy Regulations 2010 S.I. 2010/1627.

The Marine Works (Environment Impact Assessment) Regulations 2007, S.I. 2007/1518. 
The Marine Works (Environmental Impact Assessment) (Amendment) Regulations 2011, S.I. 2011/735.

The Marine Works (Environmental Impact Assessment) (Scotland) Regulations 2017, S.S.I. 2017/115.

The Offshore Marine Conservation (Natural Habitats, \& c.) Regulations 2007, S.I. $2007 / 1842$.

The Scotland Act 1998 (Concurrent Functions) Order 1999, S.I. 1999/1529.

The Scotland Act 1998 (Agency Arrangements) (Specification) Order 1999, S.I. 1999/1512. The Scottish Marine Regions Order 2015, S.S.I. 2015/193.

\section{Bibliography}

\section{Books}

Collar N, Planning (4th edn, W. Green 2016).

Woolley O, Ecological Governance Reappraising Law's Role in Protecting Ecosystem Functionality (Cambridge University Press 2014).

\section{Official Publications}

European Union (Withdrawal) Bill (HL Bill 79).

HM Government, Northern Ireland Executive, Scottish Government, Welsh Assembly Government, Marine Policy Statement (The Stationary Office 2011).

Marine Scotland, Scotland's National Marine Plan: A Single Framework for Managing Our Seas, The Scottish Government (March 2015).

Planning Circular 1/2015: The Relationship between the Statutory Land Use Planning System and Marine Planning and Licensing.

Rural Affairs, Climate Change and Environment Committee, Scottish Parliament, 2nd Report 2015 (Session 4) Report on Scotland's Marine Plan (Scottish Parliament, 30 January 2015).

\section{Journal Articles}

Scott BE and others, 'The Cooperative Participatory Evaluation of Renewable Technologies on Ecosystem Services (CORPORATES)' 2016 Scottish Marine and Freshwater Science Vol 7 No 1.

Wong CP and others, 'Linking ecosystem characteristics to final ecosystem services for public policy' (2015) 18:1 Ecology Letters 108. 


\section{Internet Sources}

Marine Scotland, Scotland's National Marine Plan Sustainability Appraisal Post Adoption Statement (March 2016) <www.gov.scot/Resource/o049/00498327.pdf> accessed 14 November 2017.

RSPB, Casework, Forth and Tay Windfarms < www.rspb.org.uk/about-the-rspb/about -us/media-centre/press-releases/rspb-scotland-plans-to-appeal-offshore-wind -farm-judicial-review/> accessed 28 September 2018.

SP Bill 25 Marine (Scotland) Bill [as introduced] Policy Memorandum Session 3 (2009) <www.parliament.scot/S3_Bills/Marine\%20(Scotland)\%2oBill/b25s3-introd-pm.pdf> accessed 30 November 2017.

The Supreme Court, Permission to appeal decisions, The Royal Society for the Protection of Birds (RSPB) (Appellant) v The Scottish Ministers and others (Respondents) (Scotland) - UKSC 2017/0143 <www.supremecourt.uk/news/permission-to-appeal -decisions-07-november-2017.html $>$ accessed 9 November 2017.

U.K. National Ecosystem Assessment (U K NEA) Progress and Steps Towards Delivery, Cambridge: UNEP-WCMC (February 2010). <http://uknea.unep-wcmc.org/Link Click.aspx?fileticket=LDV3vMdXFeY\%3D\&tabid=105 $>$ accessed 30 November 2017. 